\title{
The American University: Dilemmas and Directions
}

\author{
Ronald G. Ehrenberg
}

$\mathrm{S}$ WE APPROACH the beginning of the twenty-first
century, America's research universities are among the jewels of our higher educational system. By far the vast majority of Nobel Prize winners were educated or teach at them, and their excellence attracts graduate students from around the world. Indeed, in 1993, temporary residents earned about 25 percent of all the doctoral degrees granted by American universities. In key scientific and engineering fields, the percentages were much higher. For example, that year, temporary residents received 49 percent of the doctorates in engineering and 43 percent in the mathematical and computer sciences. ${ }^{1}$ One noted economist/academic administrator has even asserted that of the best universities in the world, two-thirds to three-quarters are in the United States. He added that similar claims of achievement could be made for very few other sectors of our economy. ${ }^{2}$

1 National Science Foundation, CASPAR Database System, vers. 4.5, Oct. 1995.

${ }^{2}$ Henry Rosovsky, The University: An Owner's Manual (New York: Norton, 1990), chap. 2. 
American research universities clearly are national treasures. Over the past decade, however, these institutions have increasingly come under attack for a wide variety of alleged sins. Further, their economic bases are increasingly being eroded because of budget problems at federal and state levels, coupled with increased demand for resources to meet competing social needs, such as health care. Thus, although American universities are national treasures, many fear they are entering a period of decline and may well prove to be an endangered species.

Why are research universities being attacked, and why are their supporters in both the private and public sectors increasingly less willing to fund them? In brief, the attacks stem from distress over the increases in tuition, which persistently have exceeded the growth of family incomes; the perception that universities are bloated bureaucracies that have overcharged the government for research; the feeling that universities display a lack of concern about undergraduate education and allow their curricula to be dictated by faculty interests rather than by what students should be learning; charges that they are too "politically correct" or not "politically correct" enough; claims that their faculty and student bodies are too diverse or not diverse enough; concerns that university faculty are producing unneeded Ph.D.s (because no jobs exist for their students) in programs that last artificially long so as to facilitate faculty members' research and the teaching of specialized courses; and concerns that some elite private research institutions have colluded with their private liberal arts college counterparts to limit financial aid awards to undergraduate students. Facing attacks of this magnitude and variety, which institutions wouldn't feel threatened.

Each of the authors of the next seven essays addresses one or more of the reasons universities are being attacked. In what follows I briefly summarize some of the key issues each author raises and offer some observations on why America's research universities 
have gotten to this point and the major challenges they will face in the future. A concluding essay by Frank H. T. Rhodes, president emeritus of Cornell University, whom this volume honors, provides his assessment of the issues and the changes universities must make if they are to remain flexible and responsive to society's needs in the years ahead.

\section{Key Points Raised by the Contributors}

William Bowen's essay focuses on the role of American research universities as vehicles of social mobility. Not only have the economic returns to education remained at historically high levels, but over the last decade attendance at institutions of aboveaverage quality has led to higher returns. ${ }^{3}$ As one might expect, this has led to fierce competition for undergraduate admission to the leading research universities, and, as a result, the students who are admitted to them have substantially higher test scores than they did in earlier years.

Bowen argues that need-based financial aid policies, which permit students of all income levels to attend leading institutions, are therefore very important. So, too, he compellingly argues, are efforts to provide opportunities for underrepresented minority students to attend these institutions. He believes that these policies, which often fall under the rubric of "affirmative action" or "diversity" policies, are important not only because a sense of "fairness" requires them but also because a diversified student body provides two types of "externalities" for students at the university and for

3 See Ronald G. Ehrenberg and Robert S. Smith, Modern Labor Economics, 6th ed. (Reading: Addison-Wesley, 1997), chap. 14, for evidence on the rates of return to college education. For recent evidence on the return to institutional quality, see Dominic J. Brewer and Ronald G. Ehrenberg, "Does It Pay to Attend an Elite Private College? Evidence from the Senior High School Class of 1980," in Research in Labor Economics, ed. Sol Polachek, vol. 14 (Greenwich, Conn.: JAI Press, 1995). 
society more generally. First, not only do the underrepresented minority students benefit, but so too do the white students, who are exposed to students from different backgrounds and with different perspectives from their own. Second, the society benefits as a whole because these institutions are training future leaders from many groups and backgrounds and, for our society to thrive, members of all groups must have the opportunity to share in its leadership. ${ }^{4}$

Bowen makes three points in response to the well-publicized fact that the test scores of underrepresented minority students admitted to selective institutions are often much lower than those of admitted white students. First, test scores are heavily influenced by a student's parents' income and educational background and, to the extent that minority applicants come from poorer and more poorly educated families, their test scores should be weighted with this fact in mind.

Second, although the average test scores of undergraduate students from minority groups are lower than those of white students, they are about the same as the test scores of white students who attended these institutions forty years ago. Thus, to the extent that the white alumni of these institutions were qualified to attend the institutions forty years ago, so the minority students are qualified to attend today.

Third, and finally, studies conducted by the Mellon Foundation using historical data from several selective universities suggest

4 In recent years, a federal appeals court decision in the Hopwood Case that dealt with the University of Texas Law School, as well as a vote by the University of California Board of Regents and a public referendum in California, have barred the use of race in admission decisions in public colleges in California, Texas, and several other states. However, the presidents of 62 leading research universities that belong to the Association of American Universities have reaffirmed the importance of campus diversity and the use of race in admission decisions. See "62 College Presidents Run Ad Backing Use of Race in Admissions," Chronicle of Higher Education, May 1997, A32. 
that test scores are very poor predictors of academic performance for underrepresented minority students. Indeed, black students with test scores roughly comparable to those of their white classmates tended to achieve no higher grades or graduation rates than their black classmates whose test scores were substantially lower than those of most of their white counterparts.

Claude Steele is among those who have discussed the reasons talented black students do not do as well in college as their test scores suggest they should. He attributes this failure at least in part to the fact that many faculty have low expectations for these students, which the students then internalize for themselves. The students also must live with the pressure that if they fail, critics of diversity policies will use their failure to condemn these policies. Thus, they carry a burden no white students carry. ${ }^{5}$

This phenomenon implies that diversity policies are not working as well on many campuses as they should. So, too, do the reports from many campuses that their student bodies often segment by racial group so that there is little contact between members of the various groups. To the extent that this occurs, some of the externalities that Bowen has hoped for are clearly not occurring.

These findings suggest to me that in the years ahead universities must devote considerably more effort to truly integrating their student bodies by breaking down racial and ethnic barriers on campus, rather than continuing to measure their success at diversifying their student bodies by focusing on the shares of underrepresented minority group members in their total student populations. This will not be an easy task. Given the extent to which American youth reside and are educated in racially segregated communities, our campuses reflect attitudes and experiences that will be hard to overcome.

5 See, for example, Claude M. Steele, "Race and the Schooling of Black Americans," Atlantic, April 1992, 68-78. 
The title of Charles Vest's contribution, "Research Universities: Overextended, Underfocused; Overstressed, Underfunded," summarizes the dilemma faced by American research universities. Vest begins by explaining how since the 1980s the research partnerships between government and academia have been breaking down. He bemoans the erroneous categorization by policy makers of research as either basic or applied, their failure to recognize research funding as a investment, and their failure to realize the implications for graduate and undergraduate education of cutbacks in research funding.

How should research universities respond in this new, less supportive environment? Vest suggests four specific goals. First, they should operate with increased efficiency and reduce the cost of education. Second, they should improve the environment for learning on campus. Third, they should use information technologies in creative ways to enhance teaching and learning. Fourth, and finally, they should realign graduate programs with the needs of society. All of these goals arise from the realization that the decline in funding has led research universities to readdress their fundamental objectives, as well as seek to improve their efficiency.

More generally, Vest notes that universities must show their supporters that they are capable of change. They must rebuild the public trust, through their words and deeds. They must reinvigorate a commitment to excellence in our society and rekindle excitement about science. Finally, they must build public support for the life of the mind. Vest believes that only if they achieve all of these aims will they gain allies and the financial support they need.

Harold Shapiro and Marye Anne Fox discuss undergraduate and graduate education respectively. Shapiro addresses only in passing the synergy between research and teaching, which many would argue is central to the American research university. Rather, his focus is on the undergraduate curriculum and the claims made 
by many critics that the curriculum and indeed undergraduate education in general no longer represent what they once did.

Shapiro provides an overview of how the undergraduate curriculum has evolved over time. His underlying message is that a wide gulf has always existed between the educational ideals espoused by critics and what teachers and students actually experienced. Put another way, he rejects the notion that there ever was a "golden age" of higher education in the United States and that we could gain anything by trying to reinstitute the curriculum of that hypothetical period.

Contemporary critics often point to the post-World War II period as the golden age. Shapiro emphasizes that our educational system at that time had many more warts than we care to remember. For example, it ignored the educational needs of the disadvantaged, paid lip service to the myth of shared values, and ignored key differences that have emerged as sources of major tension today. Indeed, charges made today of curricular incoherence, excessive specialization, and failure to project a uniform set of values were heard then as well.

Shapiro acknowledges that undergraduate education is always in need of improvement. Although he believes it is better now than it ever was, he also thinks it appears to have problems because it is not improving as rapidly as society's needs are increasing and because faculty do not devote as much time to improving the curriculum as they do to conducting research. Moreover, faculty may place too heavy an emphasis on discipline-based instruction, to the detriment of a truly successful undergraduate program. Finally, because many political, social, and cultural conflicts taking place in society are being projected on to university campuses, our undergraduate programs often fail to project a set of common values that we should be instilling in our students.

The increasing size, complexity, interdependencies, and differentiation that characterize modern higher education, together 
with the rapid expansion of knowledge bases and access to higher education, have implications that, as Shapiro emphasizes, are difficult to overestimate. At the same time, curriculum changes rarely represent the triumph of evil over good (or vice versa), although critics may claim they do. Rather, they represent an attempt to meet a new set of responsibilities implicitly placed on universities by society. Shapiro believes that in our current environment undergraduate education should place more emphasis on moral behavior and an understanding of the role of ethics.

What are the chief obstacles to improving undergraduate education? First and foremost, Shapiro believes that it is that we in academia lose sight of the fact that improving education should be our goal and resort to cultural wars rather than rational discourse over issues such as the role of individuals in their communities, the tension between tradition and change, and the reality of differences between individuals and groups.

Marye Anne Fox addresses graduate education. The poor job market in many academic fields in the early 1990s, coupled with declining levels of federal support for graduate students, has led to a lengthening of the times to degree and an increased incidence of underemployment among new doctorates. ${ }^{6}$ Faculty in many fields are now engaged in debate over whether the decline in the demand for new doctorates was a cyclical phenomenon or whether it reflected a more long-term shift in the demand for both new doctorates and faculty.

Fox comes down squarely on the side of those arguing for the need for fundamental restructuring of doctoral programs. Given the declining percentage of new doctorates who are likely to find employment in academia, or who will even end up in research

6 See Ronald G. Ehrenberg, "The Flow of New Doctorates," Journal of Economic Literature 30 (June 1992): 830-75. 
careers, she argues for broadening, rather than deepening, doctoral programs. In her view, these programs should place an increased emphasis on verbal, written, and computational skills, while providing training in a portfolio of disciplines. Someone thinking of embarking on a career as a science journalist, for example, might couple strong technical training with a study of literature.

One might question, of course, whether such trainingoriented programs could ever compete successfully with more traditional doctoral programs. Such efforts could fail because they ignore the need, at least in fields of science and engineering, for doctoral students to serve as research assistants. To the extent that faculty first train students and then reap their investment in the students, by employing them over multiple years, any attempt to alter the depth of doctoral programs will have a negative impact on faculty productivity.

I believe that, rather than a modification of the nature of Ph.D. programs, a diminution in their size is more likely. Faculty are already making increased use of "postdoctoral" appointments in their research programs. ${ }^{7}$ Rather than establishing broader academic doctoral programs, the trend may well be toward growth in income-earning professional master's programs. Some of the revenue earned from these programs could then be used to support faculty research activities.

The final three essays in the volume-by Hanna Gray, Neal Lane, and Urie Bronfenbrenner-deal with the prospects in the years ahead for specific disciplinary areas-the humanities, science and technology, and social sciences, respectively. Gray does not take the pessimistic view that some commentators have that new directions in the humanities, including critical theory, gender studies, and multicultural approaches, necessarily reflect

7 See Charles T. Clotfelter et al., Economic Challenges in Higher Education (Chicago: University of Chicago Press, 1991), 168-69. 
the deteriorating of the discipline and the prospects for genuine scholarship. ${ }^{8}$ Rather, she points out that the humanities always seem to be in crisis. This, she asserts, is probably their natural state given that they deal with complex issues that are rarely susceptible to clear-cut solutions and come under persistent attacks concerning their role in society.

As the universe that encompasses the humanities becomes more crowded and complex, it becomes more difficult to define what they are. This may not even be an important question, however, for, as Gray states, "Whether the humanities be conceived as a form of knowing, as a set of disciplines, of methodologies, or of scholarly and educational purposes, or as a way of thinking about and seeing the world, its achievements and possibilities, its questions and dilemmas, any assessment of the prospects for the role of humanistic scholarship and the breadth of liberal education in our universities must come to terms with the implications contained in these issues."

So what does the future hold for the humanities? In part, it depends on the future of universities and humanists themselves. Will they continue to be tolerant of diverse views and diverse understandings about difficult questions? Will they set standards of quality and not tolerate simplistic interpretations? According to Gray, if the answers to both these questions are yes, the future of the humanities is bright. But whether the answer will be yes is an open question in her mind.

The future of science and technology is the topic of Neal Lane's essay. Given the budget realities in Washington, Lane acknowledges that the federal investment in science and technology is at risk and that university scientists will need to do more with less. He argues that to maintain our science enterprise,

${ }^{8}$ For a more critical view of the humanities today, see Dinesh D'Souza, Illiberal Education (New York: Free Press, 1991). 
academic scientists must connect with society at large, educate society about the importance of science in everyday life, and ensure that future scientists reflect the demographic distribution of the population from which they are drawn.

Lane argues that, to win support from government and industry, universities will need to continue to break down disciplinary barriers and focus on developing cross-cutting structures to attack societal problems. In addition, university researchers will need to make more direct connections with scientists and engineers in industry. Finally, he emphasizes the continual importance of closely tying sponsored research to undergraduate education. Government sponsors, he believes, will be more willing to support research if it contributes to the educational mission and the renewal of our scientific and technical personnel.

Urie Bronfenbrenner's contribution emphasizes the fundamental role the social sciences should play in improving our nation's well-being. He argues that the great threats to our nation's quality of life often lie in the social sphere. To give one illustration of his concerns, he points out that the widening income inequality that has occurred in our society has led to a decline in the well-being of the poor in real terms in recent years. The increasing fraction of children growing up in poverty has in turn led to increases in educational failure, high rates of pregnancy among teenagers, and an increased incidence of criminal activities among our youth.

Bronfenbrenner bemoans that although social scientists appear to be as good as scientists at diagnosing problems, they do not appear to be as good at finding "cures." He attributes this discrepancy to the imprecision of social science theory and empirical evidence. Thus, he believes that a major role of social scientists in universities should be to keep students-the leaders of tomorrow-informed about social problems. If social scientists cannot solve the problems, at least they can keep students aware of them. 
Bronfenbrenner's pessimism about social scientists' abilities to prescribe cures may well be unfounded. Indeed, as an economist who has devoted much of his career to evaluating the effects of social programs and legislation, I would argue that it is unfounded. ${ }^{9}$ The social problems we observe often persist because of the unwillingness of the political process to bear the cost of curing social ills, not because social scientists have failed to prescribe appropriate cures.

\section{Facing the Future: An Economist's Perspective}

Will America's great research universities make the hard choices that will be necessary if they are to prosper in the years ahead? The authors of the essays in this volume spell out many of the issues facing universities; however, they do not, in my view, always emphasize sufficiently the inherent conflicts that erupt when there is a shrinking resource base. Economists are accustomed to thinking about how institutions seek to maximize objective functions subject to constraints. I will use such a framework in this concluding section to highlight how America's great research universities have reached their current situation and some of the trade-offs they now face. ${ }^{10}$

Each of our major research universities seeks to be of the very highest quality. Each competes for productive researchers who create new knowledge, bring research funding to the university, and help to enhance the university's stature. Over time, as the competition for faculty has heated up, it has led to lower teaching loads. In the words of two scholars, an "academic ratchet" has taken place in which faculty members' expectations about the

9 See Ehrenberg and Smith, Modern Labor Economics, for a summary of how a variety of labor market programs effect the economic well-being of individuals.

10 David Garvin, in The Economics of University Behavior (New York: Academic Press, 1980), was the first to apply such a framework to university behavior. 
fraction of their time that should be devoted to research have increased while their expectations about the fraction that should be devoted to teaching have decreased.11

Research universities also compete for undergraduate students. They have invested heavily in new academic and nonacademic facilities to attract the highest-quality students because high-quality students enhance the attractiveness of a university to faculty and to potential recruiters of the institution's graduates. The latter, in turn, further increases the attractiveness of the best universities to the highest-quality students, and students flock to these universities because of the "leg up" that the institutions give them in their quest for postcollege employment and educational opportunities. ${ }^{12}$

The quest for outstanding students was facilitated in the past by the low-tuition policies of flagship public research universities and by the major private research universities agreeing in the early 1970 s to engage in needs-blind admission policies and, with federal support, to help meet the financial needs of all students who were accepted. As a result of these policies, there has been a great increase in the socioeconomic and racial and ethnic diversity of the students who attend major private research universities, as well as a dramatic increase in the quality of the students, at least as measured by test scores. ${ }^{13}$

Great universities also compete for outstanding doctoral students. These students are important to faculty because of the roles

11 William F. Massy and Robert Zemsky, "Faculty Discretionary Time: Departments and the Academic Ratchet," Journal of Higher Education 65 (Jan. 1994): 1-22.

${ }^{12}$ See Philip J. Cook and Robert H. Frank, "The Growing Concentration of Top Students in Elite Schools," in Studies of Supply and Demand in Higher Education, ed. Charles Clotfelter and Michael Rothschild (Chicago: University of Chicago Press, 1993), 121-40.

13 See Ronald G. Ehrenberg and Susan H. Murphy, "What Price Diversity? The Death of Need-Based Financial Aid at Selective Private Colleges and Universities," Challenge 25 (July 1993): 64-73. 
they play in research and because their presence permits faculty to teach more specialized graduate courses and fewer undergraduate courses. Teaching needs in the latter areas are often met at least in part by graduate students in their roles as teaching assistants.

In their quest for excellence, great universities are constantly adding faculty in new, emerging disciplines and creating interdisciplinary programs to address social and scientific problems. They are reluctant, however, to eliminate existing programs or fields of study. Indeed, the faculty tenure system limits the flexibility of a university to change the composition of its faculty across disciplinary boundaries.

Tuition increases considerably outpaced inflation at both public and private research universities during the 1980s and in the first half of the 1990s as institutions sought to continue to enhance their quality in the face of stagnating federal and state support. Because real income growth in the economy has been zero or small for many years, tuition increases that outpaced inflation invariably led institutional financial aid budgets to increase at even more rapid rates. As a result, a substantial share of the tuition revenue at many institutions has been plowed back into institutional financial aid, thus diminishing the resources the institution has available to meet other needs. Public perceptions of university costs being "out of control" and of university decision makers being insensitive to the economic conditions facing the families of potential students now limit the ability of private research universities to continue to raise tuition by more than the rate of inflation.

The pressure on the major research universities has increased still further as federal and state funding for higher education has become more limited. Faced with competing social needs and a desire to reduce the size of government, federal and state governments reduced their rates of growth of spending for higher education, and in some cases in the mid-1990s, these rates of 
growth turned negative. Rather than thinking of federal financial aid programs for undergraduate students and federal funding of university research as investments in our nation's future, policy makers instead began to see large programs that could be cut to help reduce budget deficits.

Thus, our major research universities are truly faced with resource constraints that are increasingly becoming tighter. While one can argue, as Charles Vest does, that they must become more efficient and do more with less, one can push this line of reasoning only so far. Ultimately, these institutions must make hard choices.

Put another way, our research universities will prosper in the years ahead only if they "grow by substitution." Resources to support new and emerging fields will be found only if institutions cut back on some of their activities. Institutions, save for the very richest, will have to be selective in what they seek to accomplish. More and more of them will have to emulate the rare institutions that have publicly cut back on programs. ${ }^{14}$

With diminished support, invariably either university research will be funded increasingly from undergraduate students' tuition revenue or research productivity will decline. There are limits, noted above, on the ability of universities to raise undergraduate tuition, so the latter scenario is more likely. A corollary, however, and a point made by several of the contributors to this volume, is that faculty will need to focus more on their revenuegenerating customers and devote more time to undergraduate education. Will faculty understand that the "ratchet" must be reversible and that they must diminish the time they allocate to research? Since a large fraction of doctoral students are funded by

14 One institution that has boldly done so is the University of Rochester. See Christopher Shea, "At University of Rochester, Bad Times Prompt Bold Measures," Chronicle of Higher Education, Dec. 15, 1995, A33-A34. 
external research grants, the reduction in external funding for research will also most likely lead to a contraction in the sizes of doctoral programs. These changes will not occur because university administrators value research and doctoral education any less than they did in the past. Rather, they will occur because resource constraints dictate them.

More generally, with diminished resources, universities will have to reexamine many of their policies. William Bowen's essay very persuasively presents the case for needs-blind admission policies, need-based financial aid policies, and aggressive policies to diversify student bodies. I fully agree with his arguments. The costs of these policies may be prohibitive for many institutions, however, and we are already seeing a gradual erosion of them at all but a few institutions. ${ }^{15}$

Universities will also increasingly need to realize that there is a trade-off between the resources they devote to buildings and those they devote to people. Although many major research universities have substantial maintenance needs, spending on both research facilities and facilities designed to attract students (e.g., athletic facilities) is likely to slow down as institutions seek to provide funding to maintain faculty size and start new academic programs.

The abolition of mandatory retirement for faculty, effective in 1994, will also affect research universities. Prior research suggests that the abolition of mandatory retirement will not affect most of American higher education but that it will lead to some faculty at major private research universities delaying retirement until after the age of seventy. ${ }^{16}$ This in turn will slow down the flow of new

15 Ehrenberg and Murphy, "What Price Diversity?"

16 See, for example, Albert Rees and Sharon Smith, Faculty Retirement in the Arts and Sciences (Princeton, N.J.: Princeton University Press, 1991), and P. Brett Hammond and Harriet P. Morgan, eds., Ending Mandatory Retirement for Tenured Faculty: The Consequences for Higher Education (Washington, D.C.: National Academy Press, 1991). 
doctorates into faculty positions and increase the cost of faculty to universities. The latter will occur because, on average, full professors are paid 60 percent more than assistant professors. ${ }^{17}$ These changes will require research universities to think about ways to reduce faculty costs and maintain their flows of new faculty. Options include providing incentives for senior faculty to retire and/or placing tighter limits on the proportions of tenured faculty.

Finally, research universities will have to think more carefully about what new information technologies mean to them. On the one hand, there is the concern that new technologies may reduce the demand for residential undergraduate experiences and thus a major source of revenue for universities. ${ }^{18}$ On the other hand, as Charles Vest points out in his essay, there is the understanding that new information technologies can considerably enhance educational experiences. With this understanding, however, comes the realization that in most cases information technology increases, rather than reduces, costs. ${ }^{19}$ Furthermore, information technology is a recurring expense, not a one-time investment. Hence, methods must be found to carve funding for it out of university budgets. Whether the result is fewer faculty, less financial aid, or fewer new facilities will differ across institutions, but inevitably such choices will need to be made.

17 See "The Annual Report of the Economic Status of the Profession," published annually in the March-April or May-June issue of Academe.

18 See Eli Noam, "Electronics and the Dim Future of the University," Science, Oct. 13, 1995, 247-49.

19 An innovative attempt to use technology simultaneously to increase educational quality and to reduce university costs by providing back issues of academic journals on line, thereby reducing library space needs and handling and maintenance costs, is described in William S. Bowen, "JSTOR and the Economics of Scholarly Communication," paper presented at the conference of the Council on Library Resources, Washington, D.C., Sept. 18, 1995. 